\title{
Endothelin-1 Inhibition Improves the mBDNF/proBDNF Ratio in Endothelial Cells and HT22 Neurons Under High Glucose/Palmitate Growth Conditions
}

\author{
R. WARD ${ }^{1}$, Y. ABDUL ${ }^{2}$, A. ERGUL ${ }^{2,3}$ \\ ${ }^{1}$ Department of Neuroscience and Regenerative Medicine, Augusta University, Augusta, GA, USA, \\ ${ }^{2}$ Department of Physiology, Augusta University, Augusta, GA, USA, ${ }^{3}$ Charlie Norwood Veterans \\ Administration Medical Center, Augusta, GA, USA
}

Received December 14, 2017

Accepted April 26, 2018

\begin{abstract}
Summary
Diabetes increases the risk and worsens the progression of cognitive impairment. The hippocampus is an important domain for learning and memory. We previously showed that endothelin-1 (ET-1) reduced diabetes-induced inflammation in hippocampal neurons, suggesting a neuroprotective effect. Given that neurons and endothelial cells within the neurovascular unit depend on each other for proper function, we investigated the effect of ET-1 on brain-derived neurotrophic factor (BDNF) synthesis, a key neurotrophin and prosurvival factor, in neuronal (HT22 hippocampal neurons) and brain microvascular endothelial (BMEC-5i) cells under normal and diabetes-mimicking (high glucose plus palmitate) conditions. Cells were treated with exogenous ET-1 or ET receptor antagonists including $\mathrm{ET}_{\mathrm{B}}$ receptor selective antagonist BQ788 $(1 \mu \mathrm{M})$ or dual-receptor antagonist bosentan $(10 \mu \mathrm{M})$. Mature $(\mathrm{m}) \mathrm{BDNF}$, proBDNF and caspase- 3 levels were measured by Western blotting. Diabetic conditions reduced the prosurvival $\mathrm{mBDNF} /$ proBDNF ratio in both HT22 and BMEC-5i cells. Addition of exogenous ET-1 had no effect on the BDNF system in HT22 cells in diabetic conditions. Both HT22 and BMEC- $5 \mathrm{i}$ cells had an increase in the $\mathrm{mBDNF} /$ proBDNF ratio when grown in diabetes-simulating conditions in the presence of endothelin receptor inhibition. These data suggest that blockade of ET-1 may provide neuroprotection to hippocampal cells through the modulation of the BDNF system.
\end{abstract}

\section{Key words}

Diabetes • Mature BDNF • proBDNF • Endothelin

\section{Corresponding author}

A. Ergul, Department of Physiology, Augusta University, $112015^{\text {th }}$ Street CA-2094, Augusta, GA 30912, USA. Fax: 706-721-7299. E-mail: aergul@augusta.edu

\section{Introduction}

Diabetes is becoming a rapidly increasing problem, affecting 422 million people worldwide (WHO 2016). In addition to accepted complications associated with the disease, such as nephropathy and retinopathy, it is now known that diabetes elevates the risk and worsens progression of cognitive impairment (CDC 2017, Hardigan et al. 2016, McCrimmon et al. 2012). Learning and memory deficits as well as executive functions such as decision making are the most prominently observed form of cognitive impairment in diabetes (Kodl and Seaquist 2008, McCrimmon et al. 2012). Currently, therapeutic options are limited and as recently reviewed, one potential reason of slow progress towards finding more effective treatments due to focus on neuronal protection while neglecting neighboring cells within the brain (Iadecola 2017). Over time that led to the development of neurovascular unit concept, which includes microvascular endothelial cells, neurons, and glial cells as one unit. The effect of diabetes on close communication within this unit at the cellular level has not been well studied.

The hippocampus is a major contributor to learning and memory, contributing to critical functions such as spontaneous exploration of novel environment, formation of episodic memories and spatial memory. It is 
comprised of the hippocampus proper (CA1-4), subiculum and dentate gyrus, and it is highly sensitive to injury (Knierim 2015). The hippocampus has been shown to be a target for neurovascular changes in diabetes. Reductions in microvasculature have been reported in GK rats as well as mice fed a high fat diet (Beauquis et al. 2010, Tucsek et al. 2014). Furthermore, numerous studies in type 1 and type 2 diabetes have shown loss of dendritic spines, impaired synaptic plasticity and reduced neurogenesis in the hippocampus that are associated with cognitive impairment (Han et al. 2016, Stranahan et al. 2008, Wongchitrat et al. 2016, Zhang et al. 2016). Reductions in cerebral blood flow $(\mathrm{CBF})$ as a result of increased vascular tone has been noted in diabetic models. This decrease in CBF can negatively affect hippocampal neurons and therefore contribute to cognitive impairment. Patients and experimental models have shown endothelin-1 (ET-1), the most potent vasoconstrictor, to be elevated in diabetes (Matsumoto et al. 2004, Takahashi et al. 1990). Increased ET-1 can affect CBF and impact neuronal survival and cognition. Previously, we reported that ET-1 reduces diabetes-induced inflammation in hippocampal neurons, suggesting a neuroprotective effect (Ward and Ergul 2016). However, direct effects of ET-1 on neuroprotective pathways in hippocampal neurons in control and diabetic conditions are unknown.

Brain-derived neurotrophic factor (BDNF) has been implicated in learning and memory (Bekinschtein et al. 2014, Tyler et al. 2002). High expression of BDNF has been observed in the limbic system, which includes the hippocampus (Leibrock et al. 1989). BDNF can exert neurotrophic and angiogenic effects (Guan et al. 2012, Hempstead 2015, Liu et al. 2006). The neurotrophic roles of BDNF include development, brain plasticity and neuronal maturation. Administration of collagen-binding BDNF showed increased angiogenesis after middle cerebral artery occlusion in rats (Guan et al. 2012). Within the neurovascular unit, BDNF secreted from endothelial cells has been shown to reduce hypoxiainduced cell death in the neighboring neurons (Guo et al. 2008). Low BDNF levels in diabetic patients has been associated with cognitive impairment (Zhen et al. 2013). In experimental models, reduced BDNF contributes to cognitive dysfunction and synaptic plasticity in both obese (Wosiski-Kuhn et al. 2014) and diabetic models (Kariharan et al. 2015). Synthesis of BDNF occurs in the endoplasmic reticulum as the precursor form pre-proBDNF (Hashimoto 2016). The signal peptide is cleaved to become proBDNF. This protein can be further cleaved by proteases to become mature BDNF (mBDNF).
While mBDNF exerts neuroprotective effects through tropomyosin receptor kinase $\mathrm{B}(\mathrm{TrkB})$ receptor signaling, proBDNF has been suggested to induce neuronal apoptosis via p $75^{\mathrm{NTR}}$ receptor (Benarroch 2015, Hempstead 2015). Intracerebroventricular administration of an endothelin $\mathrm{ET}_{\mathrm{B}}$ agonist elevated BDNF mRNA levels as well as expression of the mature protein in the caudate putamen (Koyama et al. 2003). Furthermore, ET-1 increases BDNF mRNA levels and release of BDNF in astrocyte culture (Koyama et al. 2005). While studies have shown positive effects in astrocytes, little is known about the effect of ET-1 on mBDNF and proBDNF synthesis in endothelial cells and neurons. Therefore, the goal of the current study was to determine the effect of ET-1 on this major neurotrophic factor with angiogenic properties within the neurovascular unit cells under normal and disease conditions.

\section{Methods}

\section{Cell culture}

Immortalized mouse HT22 hippocampal neurons were cultured as described previously (Ward and Ergul 2016). Briefly, HT22 hippocampal cells were grown in DMEM media, supplemented with $10 \%$ FBS and $1 \%$ penicillin streptomycin cocktail in a humidified incubator at $37{ }^{\circ} \mathrm{C}$ with $5 \% \mathrm{CO}_{2}$. Due to their higher metabolic demands, HT22 cells require higher levels of glucose in normal growth media ( $25 \mathrm{mM}$ glucose) (Ward and Ergul 2016). HBEC-5i cells (ATCC), which originate from human cerebral microvascular endothelial cells, were cultured in DMEM: F-12 medium, supplemented with $10 \% \mathrm{FBS}$ and $1 \%$ penicillin streptomycin cocktail in a humidified incubator at $37{ }^{\circ} \mathrm{C}$ with $5 \% \mathrm{CO}_{2}$. To mimic a high fat diet induced in vivo model of diabetes, we used high glucose plus palmitate combination in in vitro experiments. Control media included $25 \mathrm{mM}$ and $5 \mathrm{mM}$ glucose for HT22 cells and HBEC-5i cells, respectively. High glucose/palmitate media included palmitate $(200 \mu \mathrm{M}$ in $50 \%$ ethanol) plus $50 \mathrm{mM}$ and $12.5 \mathrm{mM}$ glucose for HT22 cells and HBEC-5i cells, respectively. $12.5 \mathrm{mM}$ glucose corresponds to $\sim 225 \mathrm{mg} / \mathrm{dl}$ blood glucose levels in diet-induced model of diabetes (data not shown). As discussed above normal growth medium for HT22 cells requires $25 \mathrm{mM}$ glucose. This concentration was doubled to mimic diabetes conditions. Before all experiments, cells were serum starved for $6 \mathrm{~h}$. HT22 cells were treated with ET-1 $(10,50,100 \mathrm{nM})$ for $24 \mathrm{~h}$. In a second set of experiments, activation of ET receptors by endogenous ET-1 was blocked by either the dual-receptor antagonist 
bosentan $(10 \mu \mathrm{M})$ or the $\mathrm{ET}_{\mathrm{B}}$ selective antagonist BQ788 $(1 \mu \mathrm{M})$ in both HT22 and BMEC-5i cells.

\section{Western blot analysis}

Cells were harvested after experiments and lysed using a modified RIPA buffer (Millipore Billerica, MA, USA). Equal protein loads were boiled in sample buffer and separated on a 4-15\% Mini-PROTEAN TGX gel by electrophoresis, then transferred by Trans-Blot Turbo system (Bio-Rad Laboratories, Inc., Hercules, CA, USA) onto a nitrocellulose membrane. Membranes were probed for caspase-3 (Cell Signaling, Danvers, MA, USA), mBDNF and proBDNF (Thermofisher Scientific, Waltham, MA, USA) at a concentration of 1:500. Expression was standardized using $\beta$-actin. Band intensity was analyzed using ImageJ software.

\section{Statistical analysis}

All data points were expressed as mean \pm SEM. Prism7 was used for all analyses. Interaction of condition (control, diabetes) and either exogenous ET-1 (0, 10, 50, $100 \mu \mathrm{M}$ ) or inhibition (no treatment, bosentan, BQ788) on BDNF or caspase-3 expression was analyzed by two-way ANOVA. Bonferroni's post hoc test was used to compare means from significant ANOVAs. Statistical significance was determined at alpha $<0.05$.

\section{Results}

High glucose/palmitate growth conditions alter the BDNF system and increase apoptosis in neuronal and endothelial cell lines

Diabetes-mimicking conditions increased proBDNF with a concomitant decrease in mBDNF as determined by immunoblotting in both HT22 (Fig.1A) and endothelial cells (Fig. 1B). Caspase-3 was increased in HT22 cells grown in diabetic conditions (Fig. 1C). While no significance was observed in HBEC-5i cells, there was a trend towards elevated caspase- 3 in diabetic conditions ( $p=0.054$; Fig. 1D).
A.

c.

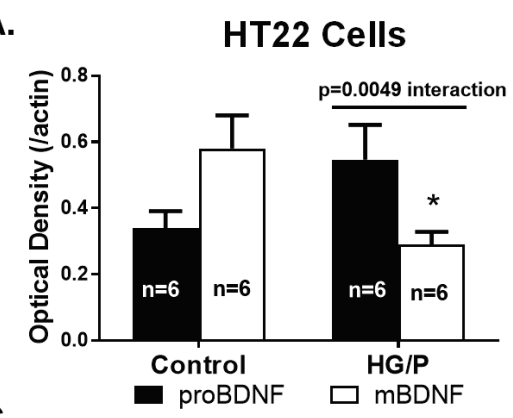

Caspase-3

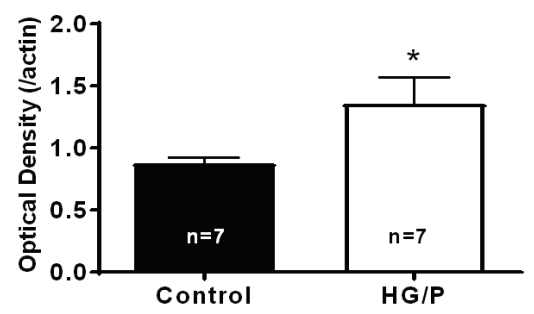

B.

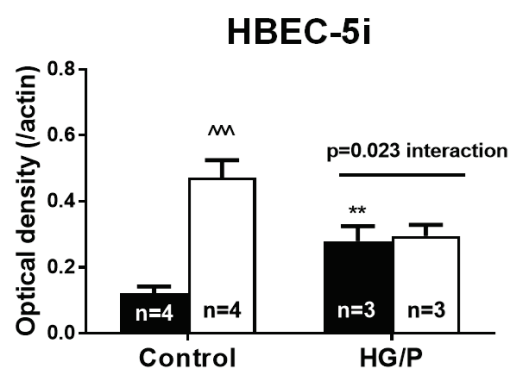

D.

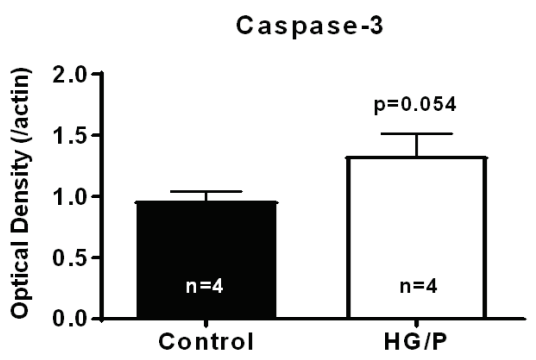

Fig. 1. Diabetes-mimicking growth conditions (HG/P) increase proBDNF and decrease mBDNF protein levels in both HT22 (A: P Interaction=0.0049, $\mathrm{F}(1,22)=9.796 ; \quad P_{\text {diabetes }}=0.6054$, $\mathrm{F}(1,22)=0.2747 ; \quad \mathrm{P}_{\mathrm{BDNF}}=0.9301$, $F(1,22)=0.0079) \quad$ and HBEC-5i (B: $P_{\text {Interaction }}=0.0023, F(1,10)=16.42$; $P_{\text {diabetes }}=0.8208, \quad F(1,10)=0.0541$; $\mathrm{P}_{\mathrm{BDNF}}=0.0012, \mathrm{~F}(1,10)=19.77$ ) cells as indicated by the quantification of corresponding bands on Western blots. Furthermore, caspase- 3 was increased in high glucose/palmitate conditions (C-D). Control media included $25 \mathrm{mM}$ and $5 \mathrm{mM}$ glucose for HT22 cells and HBEC-5i cells, respectively. High glucose/palmitate media included palmitate $(200 \mu \mathrm{M}$ in $50 \%$ ethanol) plus $50 \mathrm{mM}$ and $12.5 \mathrm{mM}$ glucose for HT22 cells and HBEC-5i cells, respectively. $*_{\mathrm{p}}<0.05$ vs. control; $\wedge \wedge \wedge p<0.001$ vs. proBDNF.
Effects of exogenous endothelin on HT22 hippocampal cells

Since we previously showed reduced inflammation after treatment with exogenous ET-1 in HT22 cells (Ward and Ergul 2016), we next wanted to investigate the effect of ET-1 on BDNF synthesis and cell death. ET-1 had no effect on proBDNF levels in either control or diabetes-mimicking conditions (Fig. 2A). Under control conditions, there was a trend for decreased mBDNF (Fig. 2B) along with increased apoptotic marker caspase-3 (Fig. 2C). While exogenous ET-1 did not change mBDNF levels in high glucose/palmitate growth conditions, there was a trend for reduced apoptosis with ET-1 (Fig. 2C).

Effects of endothelin receptor antagonism in HT22 and HBEC-5i cells

The next experiments aimed to understand the role of endogenous ET-1 on the endothelial and neuronal BDNF synthesis. HT22 cells treated with the dualreceptor antagonist bosentan showed no significant differences in the BDNF system expression grown under 
diabetes-mimicking conditions. Cells grown under control plus bosentan conditions had increased proBDNF expression without subsequent changes to mBDNF (Figs 3A and 3B). Unlike the dual receptor blockade, inhibition of the $\mathrm{ET}_{\mathrm{B}}$ receptor alone with BQ788 improved the mBDNF/proBDNF ratio in HT22 neurons (Fig. 3C). Furthermore, treatment with BQ788 showed a trend towards decreased caspase- 3 expression ( $p=0.0674$; Fig. 3D).
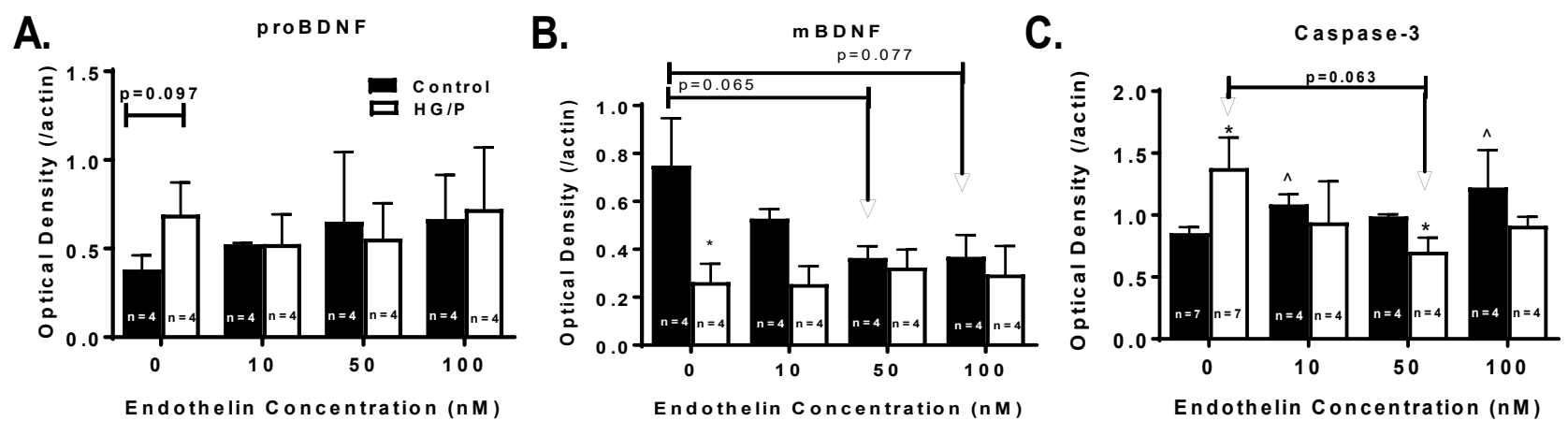

Fig. 2. Exogenous ET-1 has no effect on the BDNF system in HT22 cells. While diabetes-mimicking conditions (HG/P) alone reduced mBDNF, addition of exogenous ET-1 in increasing concentrations did not change protein expression of proBDNF (A) or mBDNF as determined by immunoblotting (B). Band intensity corresponding to caspase-3 expression was increased in high glucose/palmitate conditions. Control media included $25 \mathrm{mM}$ and $5 \mathrm{mM}$ glucose for HT22 cells and HBEC-5i cells, respectively. High glucose/palmitate media included palmitate (200 $\mathrm{MM}$ in $50 \%$ ethanol) plus $50 \mathrm{mM}$ and $12.5 \mathrm{mM}$ glucose for HT22 cells and HBEC-5i cells, respectively. ${ }^{*} \mathrm{p}<0.05$ vs. control; $\wedge p<0.05$ vs. $0 \mu \mathrm{M}$ ET-1.

A.

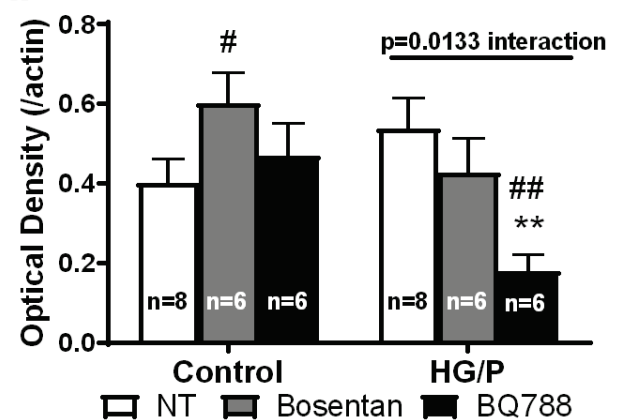

B.

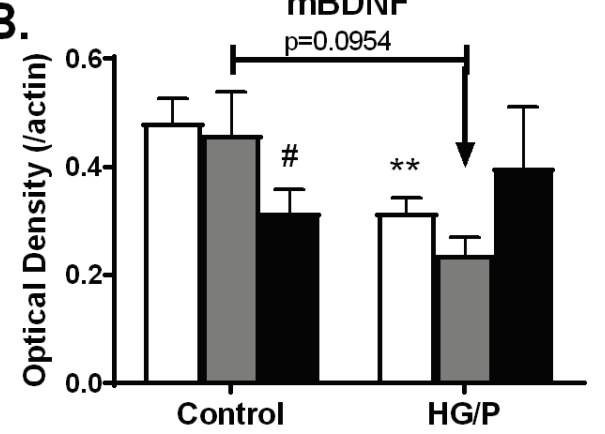

C.

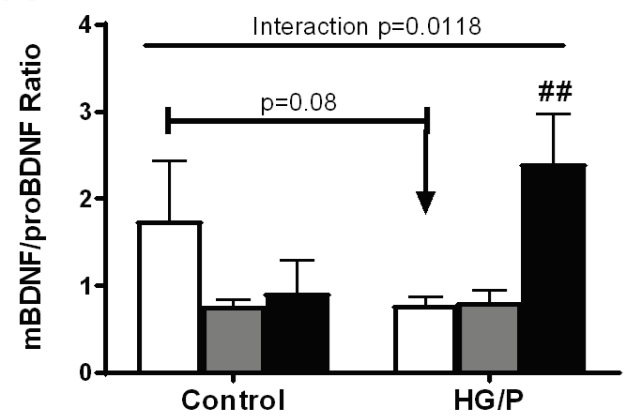

D.

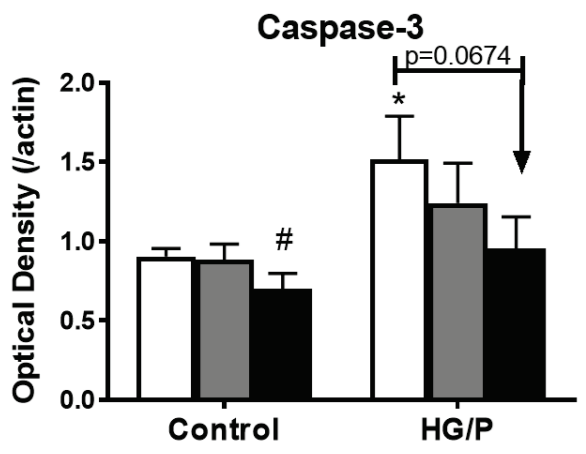

Fig. 3. Protein expression of proBdNF (A: $P_{\text {Interaction }}=0.0133, F(2,34)=4.917 ; \quad P_{\text {diabetes }}=0.0781, F(1,34)=3.301 ; \quad P_{\text {treatment }}=0.0463$, $F(2,34)=3.369)$ and $m B D N F\left(B: P_{\text {Interaction }}=0.0579, F(2,29)=3.148 ; P_{\text {diabetes }}=0.0666, F(1,29)=3.632 ; P_{\text {treatment }}=0.7113, F(2,29)=0.3447\right)$ was measured after $24 \mathrm{~h}$ of ET receptor inhibition in HT22 cells by quantification of immunoblots. Dual-receptor antagonism with bosentan increased expression of proBDNF in control conditions. Inhibition of $\mathrm{ET}_{\mathrm{B}}$ with $\mathrm{BQ788}(1 \mu \mathrm{M})$, but not dual-receptor antagonism with bosentan $(10 \mu \mathrm{M})$, increased the $\mathrm{mBDNF} /$ proBDNF ratio in diabetes-mimicking conditions $\left(\mathbf{C}\right.$ : $\mathrm{P}_{\text {Interaction }}=0.0118, F(2,29)=5.194$; $\left.P_{\text {diabetes }}=0.5492, F(1,29)=0.3673 ; P_{\text {treatment }}=0.0806, F(2,29)=2.749\right)$. Cell death marker caspase- 3 was elevated in high glucose/palmitate growth conditions and had a decreased trend after ET receptor inhibition (D: $P_{\text {Interaction }}=0.5722, F(2,26)=0.5722 ; P_{\text {diabetes }}=0.0079$, $\left.F(1,26)=8.276 ; P_{\text {treatment }}=0.1071, F(2,26)=2.438\right)$. Control media included $25 \mathrm{mM}$ and $5 \mathrm{mM}$ glucose for HT22 cells and HBEC-5i cells, respectively. High glucose/palmitate media included palmitate $(200 \mu \mathrm{M}$ in $50 \%$ ethanol) plus $50 \mathrm{mM}$ and $12.5 \mathrm{mM}$ glucose for HT22 cells and HBEC- $5 i$ cells, respectively. $* p<0.05, * * p<0.01$ vs. control; $\# p<0.05, \# \# p<0.01$ vs. NT. 
A.

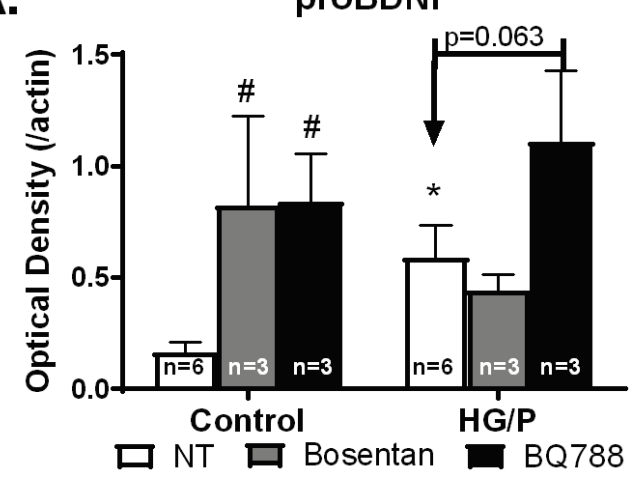

B.

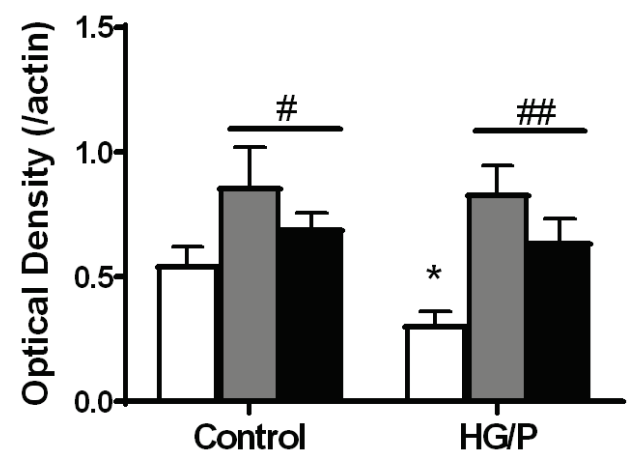

C.

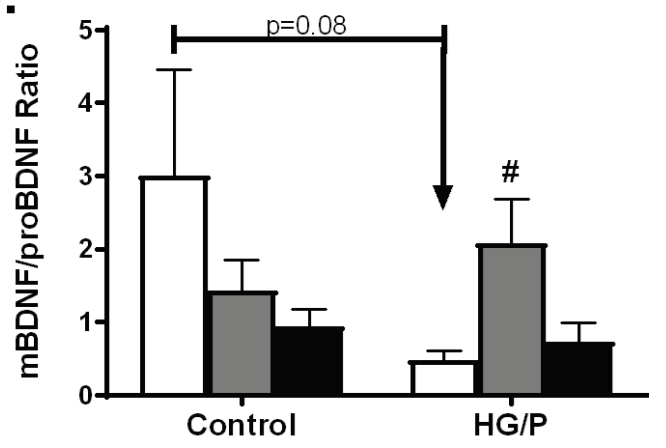

D.

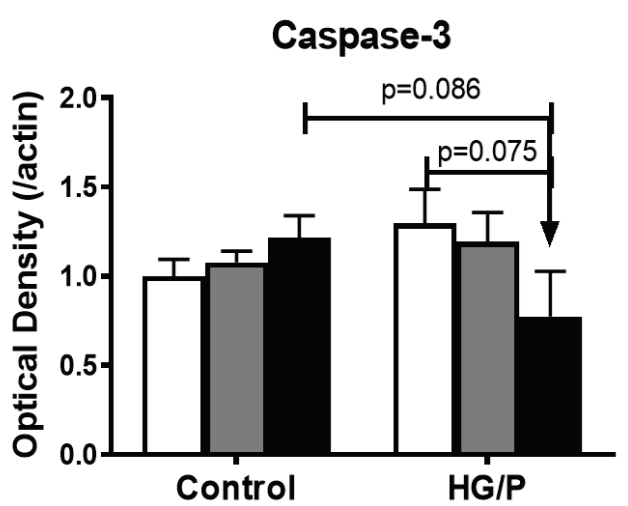

Fig. 4. Protein expression of proBDNF (A: $P_{\text {Interaction }}=0.1294, F(2,18)=2.296 ; P_{\text {diabetes }}=0.5384, F(1,18)=0.3934 ; P_{\text {treatment }}=0.0186$, $F(2,18)=5.016)$ and $\operatorname{mBDNF}\left(\mathbf{B}: P_{\text {Interaction }}=0.3893, F(2,17)=0.9978 ; P_{\text {diabetes }}=0.1691, F(1,17)=2.062 ; P_{\text {treatment }}=0.0004, F(2,17)=12.65\right)$ was measured after $24 \mathrm{~h}$ of ET receptor inhibition in HBEC-5i cells by quantification of immunoblots. In diabetes-mimicking conditions, dual-receptor blockade $(10 \mu \mathrm{M})$ improved mBDNF to proBDNF ratio $\left(\mathbf{C}: P_{\text {Interaction }}=0.0947, F(2,12)=2.888 ; P_{\text {diabetes }}=0.2391\right.$, $\left.F(1,12)=1.535 ; P_{\text {treatment }}=0.3350, F(2,12)=1.2\right)$. Caspase-3 expression had no significant changes in diabetic or ET receptor inhibition in HBEC-5i cells $\left(D\right.$ : $\left.P_{\text {Interaction }}=0.0855, F(2,18)=2.828 ; P_{\text {diabetes }}=0.9445, F(1,18)=0.00498 ; P_{\text {treatment }}=0.5776, F(2,18)=0.566\right)$. Control media included $25 \mathrm{mM}$ and $5 \mathrm{mM}$ glucose for HT22 cells and HBEC-5i cells, respectively. High glucose/palmitate media included palmitate $\left(200 \mu \mathrm{M}\right.$ in $50 \%$ ethanol) plus $50 \mathrm{mM}$ and $12.5 \mathrm{mM}$ glucose for HT22 cells and HBEC-5i cells, respectively. ${ }^{*} \mathrm{p}<0.05$ vs. control; $\# p<0.05, \# \# p<0.01$ vs. NT.

While proBDNF expression was increased after treatment with bosentan or BQ788 in HBEC-5i cells under control conditions, in diabetes-mimicking in vitro conditions proBDNF was increased even in untreated cells. Bosentan had no effect but BQ788 further increased proBDNF levels. High glucose/palmitate growth conditions reduced $\mathrm{mBDNF}$ and endothelin inhibition increased mBDNF (Figs 4A and 4B). In BMEC-5i cells, bosentan improved the $\mathrm{mBDNF} /$ proBDNF ratio in cells grown under diabetes-mimicking conditions (Fig. 4C). While no significant difference was found in caspase-3 expression in these cells, endothelin inhibition trended towards reduced expression ( $p=0.075$; Fig. 4D).

\section{Discussion}

The current study provides novel insights into the regulation of BDNF synthesis by ET-1 within cells of the neurovascular unit. Our results showed that in diabetes-mimicking conditions 1) mBDNF/proBDNF ratio was reduced in both hippocampal neurons and brain endothelial cells; 2) exogenous ET-1 had opposite effects on neuronal apoptosis compared to control, and 3) inhibition of endogenous ET-1 signaling improved the $\mathrm{mBDNF} /$ proBDNF ratio.

Cognitive impairment is increasingly considered as a diabetic complication, yet remains one of the less understood complications associated with the disease. With a greater number of younger patients being diagnosed with diabetes each year (Benjamin et al. 2017, D'Adamo and Caprio 2011, Ehehalt et al. 2008, Kumar et al. 2008), this problem needs to be a target of study. In type 2 diabetic patients, the most common deficits have been observed in the areas of attention, memory, executive function and information processing (Palta et al. 2014, van den Berg et al. 2009). These deficits have been noted in early diabetes and even in pre-diabetic patients (Crichton et al. 2012, Ruis et al. 2009). As a critical domain of learning and memory, the hippocampus has been the focus of numerous studies 
relating to diabetes and cognition. Experimental diabetic models such as Goto-Kakizaki (GK) rats, high fat diet plus low dose streptozotocin, Zucker rats and $\mathrm{db} / \mathrm{db}$ mice have all been shown to develop hippocampal-dependent cognitive deficits (Li et al. 2002, Ramos-Rodriguez et al. 2013, Stranahan et al. 2008). Loss of dendritic spine, impaired synaptic plasticity and low neurogenesis rates in the hippocampus have been reported to contribute to the cognitive impairment seen in diabetes ( $\mathrm{Li}$ et al. 2013, Stranahan et al. 2008, Wongchitrat et al. 2016, Zhang et al. 2016). ET-1 can contribute to these changes via regulation of blood flow in hippocampus as well as direct effects on neuronal survival and function. While some studies suggested that stimulation of the endothelin B receptor by IRL-1620 reduces neuronal damage after ischemic injury as well as improving cognitive deficits in type 1 diabetic rats and in a rat model of Alzheimer's disease $(A D)$ in which disease is induced by injection of amyloid $B(A \beta 1-40)$ in the lateral cerebral ventircles (Briyal et al. 2015, Briyal et al. 2014, Leonard et al. 2011, Leonard et al. 2012), other studies suggested that inhibition of the ET system was beneficial in improving outcomes. For example, $\mathrm{ET}_{\mathrm{A}}$ receptor antagonists prevented cognitive dysfunction in $\mathrm{AD}$ while the dual $\mathrm{ET}_{\mathrm{A}} / \mathrm{ET}_{\mathrm{B}}$ receptor antagonist TAK-044 had no effect in this model (Briyal et al. 2011). Treatment with another dual receptor blocker bosentan has been reported to improve learning and memory in a similar yet slightly different model of AD (Singh and Prakash 2017). Hung et al. (2015) observed severe spatial learning and memory deficits after stroke in transgenic mice overexpressing astrocytic ET-1 as well as cognitive dysfunction in animals in which ET-1 is overexpressed in endothelial cell (Zhang et al. 2013). In support of these studies, lower levels of plasma ET-1 was associated with better cognition in children (Calderon-Garciduenas et al. 2013). Understanding how ET-1 modulates growth factors that are critical for the survival of different cell types within the hippocampus in health and disease conditions may provide critical insights to novel treatments for this complication. In the current study, we show that ET inhibition with bosentan modulates BDNF synthesis while decreasing caspase- 3 protein expression in HT22 and BMEC-5i cells grown in high glucose/palmitate containing growth conditions to simulate diabetic conditions. This suggests that blocking endothelin signaling may improve cell survival.

Neurotrophins, such as BDNF, are important to the central nervous system and play a role in neuronal survival. BDNF signaling is critical in learning and memory through neuronal maturation and plasticity (Iadecola 2017, Wosiski-Kuhn et al. 2014). The hippocampus in particular has robust expression of BDNF and its main receptor TrkB. Mature BDNF binds to TrkB, which leads to autophosphorylation of the receptor and downstream signaling cascades such as the MAPK pathway, phosphatidylinositol 3-kinase-Akt pathway, phosoholipase 3 pathway and CaMK pathway. The proBDNF form can activate $\mathrm{p} 75^{\mathrm{NTR}}$ and promote apoptosis (Harte-Hargrove et al. 2013, Hempstead 2015). BDNF and its receptors are synthesized not only in neurons, but also in endothelial cells, smooth muscle cells and glial cells (Donovan et al. 2000, Ejiri et al. 2005, Tasci et al. 2012). Interestingly, within the neurovascular unit, BDNF secreted by endothelial cells has been shown to protect neurons from hypoxia or amyloid-induced cell death (Guo et al. 2008). Reductions in BDNF have been noted in diabetic patients and experimental models that also present with cognitive dysfunction but the relative ratio of mBDNF/proBDNF has not been well studied (Boyuk et al. 2014, Kariharan et al. 2015, Reus et al. 2016, Utkan et al. 2015, Zhen et al. 2013). In the present study, we confirm reductions of mBDNF in neuronal and endothelial cell lines grown in diabetes-simulating growth conditions. Furthermore, we show a subsequent increase in protein expression of proBDNF, which may play a role in increased cell death in the diabetic brain. Here, we provide additional evidence that inhibition of the endothelin receptors improves the $\mathrm{mBDNF} /$ proBDNF ratio. This suggests that perhaps blocking ET-1 action in the diabetic brain may improve neuronal function and decrease cell death within the neurovascular unit by improving vasotrophic coupling. Further in vivo studies need to be conducted to determine if endothelin blockade would prevent diabetes-induced pathological neurovascular remodeling of the hippocampus and improve cognitive function.

The current study has several limitations that should be identified. First, in order to study the regulation of $\mathrm{mBDNF} / \mathrm{proBDNF}$ in different cells of the neurovascular unit, we only used an in vitro approach in cell lines rather than in vivo studies. Secondly, we measured solely caspase- 3 as a marker of cell death and did not perform additional cell viability experiments. Third, we did not investigate endothelin receptor subtype expression under control and diabetes-simulating conditions. However, in a related study, we observed that endothelial cells used in this current study (HBEC-5i) 
possess both $\mathrm{ET}_{\mathrm{A}}$ and $\mathrm{ET}_{\mathrm{B}}$ receptors and inhibition by dual blockade reduces regulated cell death (Abdul et al. 2018). Nevertheless, our data showing that inhibition of endothelin receptors improves the mBDNF/proBDNF ratio in both neurons and endothelial cells grown in diabetic conditions and supports the notion that ET-1 may contribute to the development and progression of cognitive dysfunction in diabetes by modulating the BDNF synthesis to promote cell death rather than survival.

\section{Conflict of Interest}

\section{References}

ABDUL Y, WARD R, DONG G, ERGUL A: Lipopolysaccharide-induced necroptosis of brain microvascular endothelial cells can be prevented by inhibition of endothelin receptors. Physiol Res 67 (Suppl 1): S227-S236, 2018.

BEAUQUIS J, HOMO-DELARCHE F, GIROIX MH, EHSES J, COULAUD J, ROIG P, PORTHA B, DE NICOLA AF, SARAVIA F: Hippocampal neurovascular and hypothalamic-pituitary-adrenal axis alterations in spontaneously type 2 diabetic GK rats. Exp Neurol 222: 125-134, 2010.

BEKINSCHTEIN P, CAMMAROTA M, MEDINA JH: BDNF and memory processing. Neuropharmacology 76: 677-683, 2014.

BENARROCH EE: Brain-derived neurotrophic factor: regulation, effects and potential clinical relevance. Neurology 84: 1693-1704, 2015.

BENJAMIN EJ, BLAHA MJ, CHIUVE SE, CUSHMAN M, DAS SR, DEO R, DE FERRANTI SD, FLOYD J, FORNAGE M, GILLESPIE C, ET AL.: Heart disease and stroke statistics - 2017 update: a report from the American Heart Association. Circulation 135: e146-e603, 2017.

BOYUK B, DEGIRMENCIOGLU S, ATALAY H, GUZEL S, ACAR A, CELEBI A, EKIZOGLU I, SIMSEK C: Relationship between levels of brain-derived neurotrophic factor and metabolic parameters in patients with type 2 diabetes mellitus. J Diabetes Res 2014: 978143, 2014.

BRIYAL S, PHILIP T, GULATI A: Endothelin-A receptor antagonists prevent amyloid-beta-induced increase in ETA receptor expression, oxidative stress, and cognitive impairment. J Alzheimers Dis 23: 491-503, 2011.

BRIYAL S, SHEPARD C, GULATI A: Endothelin receptor type B agonist, IRL-1620, prevents beta amyloid (Abeta) induced oxidative stress and cognitive impairment in normal and diabetic rats. Pharmacol Biochem Behav 120: 65-72, 2014.

BRIYAL S, NGUYEN C, LEONARD M, GULATI A: Stimulation of endothelin B receptors by IRL-1620 decreases the progression of Alzheimer's disease. Neuroscience 301: 1-11, 2015.

CALDERON-GARCIDUENAS L, MORA-TISCARENO A, FRANCO-LIRA M, CROSS JV, ENGLE R, ARAGONFLORES M, GOMEZ-GARZA G, JEWELLS V, MEDINA-CORTINA H, SOLORIO E, CHAO CK, ZHU H, MUKHERJEE PS, FERREIRA-AZEVEDO L, TORRES-JARDÓN R, D'ANGIULLI A: Flavonol-rich dark cocoa significantly decreases plasma endothelin-1 and improves cognition in urban children. Front Pharmacol 4: 104, 2013.

CDC: National Diabetes Statistics Report. Centers of Disease Control and Prevention, U.S. Department of Health and Human Services, Atlanta, GA, 2017, 20 p.

CRICHTON GE, ELIAS MF, BUCKLEY JD, MURPHY KJ, BRYAN J, FRISARDI V: Metabolic syndrome, cognitive performance, and dementia. J Alzheimers Dis 30 (Suppl 2): S77-S87, 2012.

D'ADAMO E, CAPRIO S: Type 2 diabetes in youth: epidemiology and pathophysiology. Diabetes Care 34 (Suppl 2): S161-S165, 2011. 
DONOVAN MJ, LIN MI, WIEGN P, RINGSTEDT T, KRAEMER R, HAHN R, WANG S, IBANEZ CF, RAFII S, HEMPSTEAD BL: Brain derived neurotrophic factor is an endothelial cell survival factor required for intramyocardial vessel stabilization. Development 127: 4531-4540, 2000.

EHEHALT S, BLUMENSTOCK G, WILLASCH AM, HUB R, RANKE MB, NEU A, BADEN-WURTTEMBERG DI: Continuous rise in incidence of childhood type 1 diabetes in Germany. Diabet Med 25: 755-757, 2008.

EJIRI J, INOUE N, KOBAYASHI S, SHIRAKI R, OTSUI K, HONJO T, TAKAHASHI M, OHASHI Y, ICHIKAWA S, TERASHIMA M, MORI T, AWANO K, SHINKE T, SHITE J, HIRATA K, YOKOZAKI H, KAWASHIMA S, YOKOYAMA M: Possible role of brain-derived neurotrophic factor in the pathogenesis of coronary artery disease. Circulation 112: 2114-2120, 2005.

GUAN J, TONG W, DING W, DU S, XIAO Z, HAN Q, ZHU Z, BAO X, SHI X, WU C, CAO J, YANG Y, MA W, LI G, YAO Y, GAO J, WEI J, DAI J, WANG R: Neuronal regeneration and protection by collagen-binding BDNF in the rat middle cerebral artery occlusion model. Biomaterials 33: 1386-1395, 2012.

GUO S, KIM WJ, LOK J, LEE SR, BESANCON E, LUO BH, STINS MF, WANG X, DEDHAR S, LOW EH: Neuroprotection via matrix-trophic coupling between cerebral endothelial cells and neurons. Proc Natl Acad Sci U S A 105: 7582-7587, 2008.

HAN H, WU LM, HAN MX, YAN WM, WANG YX, FANG ZH: Diabetes impairs spatial learning and memory and hippocampal neurogenesis via BDNF in rats with transient global ischemia. Brain Res Bull 124: 269-277, 2016.

HARDIGAN T, WARD R, ERGUL A: Cerebrovascular complications of diabetes: focus on cognitive dysfunction. Clin Sci (Lond) 130: 1807-1822, 2016.

HARTE-HARGROVE LC, MACLUSKY NJ, SCHARFMAN HE: Brain-derived neurotrophic factor-estrogen interactions in the hippocampal mossy fiber pathway: implications for normal brain function and disease. Neuroscience 239: 46-66, 2013.

HASHIMOTO K: Regulation of brain-derived neurotrophic factor (BDNF) and its precursor proBDNF in the brain by serotonin. Eur Arch Psychiatry Clin Neurosci 266: 195-197, 2016.

HEMPSTEAD BL: Brain-derived neurotrophic factor: three ligands, many actions. Trans Am Clin Climatol Assoc 126: 9-19, 2015.

HUNG VK, YEUNG PK, LAI AK, HO MC, LO AC, CHAN KC, WU EX, CHUNG SS, CHEUNG CW, CHUNG SK: Selective astrocytic endothelin-1 overexpression contributes to dementia associated with ischemic stroke by exaggerating astrocyte-derived amyloid secretion. J Cereb Blood Flow Metab 35: 1687-1696, 2015.

IADECOLA C: The neurovascular unit coming of age: a journey through neurovascular coupling in health and disease. Neuron 96: 17-42, 2017.

KARIHARAN T, NANAYAKKARA G, PARAMESHWARAN K, BAGASRAWALA I, AHUJA M, ABDELRAHMAN E, AMIN AT, DHANASEKARAN M, SUPPIRAMANIAM V, AMIN RH: Central activation of PPAR-gamma ameliorates diabetes induced cognitive dysfunction and improves BDNF expression. Neurobiol Aging 36: 1451-1461, 2015.

KNIERIM JJ: The hippocampus. Curr Biol 25: R1116-R1121, 2015.

KODL CT, SEAQUIST ER: Cognitive dysfunction and diabetes mellitus. Endocr Rev 29: 494-511, 2008.

KOYAMA Y, TSUJIKAWA K, MATSUDA T, BABA A: Intracerebroventricular administration of an endothelin ETB receptor agonist increases expressions of GDNF and BDNF in rat brain. Eur J Neurosci 18: 887-894, 2003.

KOYAMA Y, TSUJUKAWA K, MATSUDA T, BABA A: Endothelin increases expression of exon III- and exon IV-containing brain-derived neurotrophic factor transcripts in cultured astrocytes and rat brain. $J$ Neurosci Res 80: 809-816, 2005.

KUMAR P, KRISHNA P, REDDY SC, GURAPPA M, ARAVIND SR, MUNICHOODAPPA C: Incidence of type 1 diabetes mellitus and associated complications among children and young adults: results from Karnataka Diabetes Registry 1995-2008. J Indian Med Assoc 106: 708-711, 2008.

LIEBROCK J, LOTTSPEICH F, HOHN AM, HOFER M, HENGERER B, MASIAKOWSKI P, THOENEN H, BARDE YA: Molecular cloning and expression of brain-derived neurotrophic factor. Nature 341: 149-152, 1989. 
LEONARD MG, BRIYAL S, GULATI A: Endothelin B receptor agonist, IRL-1620, reduces neurological damage following permanent middle cerebral artery occlusion in rats. Brain Res 1420: 48-58, 2011.

LEONARD MG, BRIYAL S, GULATI A: Endothelin B receptor agonist, IRL-1620, provides long-term neuroprotection in cerebral ischemia in rats. Brain Res 1464: 14-23, 2012.

LI XH, XIN X, WANG Y, WU JZ, KIN ZD, MA LN, NIE CJ, XIAO X, HU Y, JIN MW: Pentamethylquercetin protects against diabetes-related cognitive deficits in diabetic Goto-Kakizaki rats. J Alzheimers Dis 34: 755-767, 2013.

LI XL, AOU S, OOMURA Y, HORI N, FUKUNAGA K, HORI T: Impairment of long-term potentiation and spatial memory in leptin receptor-deficient rodents. Neuroscience 113: 607-615, 2002.

LIU Y, SUN L, HUAN Y, ZHAO H, DENG J: Application of bFGF and BDNF to improve angiogenesis and cardiac function. J Surg Res 136: 85-91, 2006.

MATSUMOTO T, YOSHIYAMA S, KOBAYASHI T, KAMATA K: Mechanisms underlying enhanced contractile response to endothelin-1 in diabetic rat basilar artery. Peptides 25: 1985-1994, 2004.

MCCRIMMON RJ, RYAN CM, FRIER BM: Diabetes and cognitive dysfunction. Lancet 379: 2291-2299, 2012.

PALTA P, SCHNEIDER AL, BIESSELS GJ, TOURADJI P, HILL-BRIGGS F: Magnitude of cognitive dysfunction in adults with type 2 diabetes: a meta-analysis of six cognitive domains and the most frequently reported neuropsychological tests within domains. J Int Neuropsychol Soc 20: 278-291, 2014.

RAMOS-RODRIGUEZ JJ, ORTIZ O, JIMENEZ-PALOMARES M, KAY KR, BERROCOSO E, MURILLOCARRETERO MI, PERDOMO G, SPIRES-JONES T, COZAR-CASTELLANO I, LECHUGA-SANCHO AM, GARCIA-ALLOZA M: Differential central pathology and cognitive impairment in pre-diabetic and diabetic mice. Psychoneuroendocrinology 38: 2462-2475, 2013.

REUS GZ, BERNARDINI DOS SANTOS MA, ABELAIRA HM, MACIEL AL, ARENT CO, MATIAS BI, BRUCHCHEN L, IGNACIO ZM, MICHELS M, DAL-PIZZOL F, CARVALHO AF, ZUGNO AI, QUEVEDO J: Antioxidant therapy alters brain MAPK-JNK and BDNF signaling pathways in experimental diabetes mellitus. Curr Neurovasc Res 13: 107-114, 2016.

RUIS C, BIESSELS GJ, GORTER KJ, VAN DEN DONK M, KAPPELLE LJ, RUTTEN GE: Cognition in the early stage of type 2 diabetes. Diabetes Care 32: 1261-1265, 2009.

SINGH M, PRAKASH A: Possible role of endothelin receptor against hyperhomocysteinemia and beta amyloid induced AD type of vascular dementia in rats. Brain Res Bull 133: 31-41, 2017.

STRANAHAN AM, ARUMUGAM TV, CUTLER RG, LEE K, EGAN JM, MATTSON MP: Diabetes impairs hippocampal function through glucocorticoid-mediated effects on new and mature neurons. Nat Neurosci 11: 309-317, 2008.

TAKAHASHI K, GHATEI MA, LAM HC, O'HALLORAN DJ, BLOOM SR: Elevated plasma endothelin in patients with diabetes mellitus. Diabetologia 33: 306-310, 1990.

TASCI I, KABUL HK, AYDOGDU A: Brain derived neurotrophic factor (BDNF) in cardiometabolic physiology and disease. Anadolu Kardiyol Derg 12: 684-688, 2012.

TUCSEK Z, TOTH P, TARANTINI S, SOSNOWSKA D, GAUTAM T, WARRINGTON JP, GILES CB, WREN JD, KOLLER A, BALLABH P, SONNTAG WE, UNGVARI Z, CSISZAR A: Aging exacerbates obesity-induced cerebromicrovascular rarefaction, neurovascular uncoupling, and cognitive decline in mine. J Gerontol A Biol Sci Med Sci 69: 1339-1352, 2014.

TYLER WJ, ALONSO M, BRAMHAM CR, POZZO-MILLWE LD: From acquisition to consolidation: on the role of brain-derived neurotrophic factor signaling in hippocampal-dependent learning. Learn Mem 9: 224-237, 2002.

UTKAN T, YAZIR Y, KARSON A, BAYRAMGURLER D: Etanercept improves cognitive performance and increases eNOS and BDNF expression during experimental vascular dementia in streptozotocin-induced diabetes. Curr Neurovasc Res 12: 135-146, 2015.

VAN DEN BERG E, KLOPPENBORG RP, KESSELS RP, KAPPELLE LJ, BIESSELS GJ: Type 2 diabetes mellitus, hypertension, dyslipidemia and obesity: a systematic comparison of their impact on cognition. Biochem Biophys Acta 1792: 470-481, 2009.

WARD R, ERGUL A: Relationship of endothelin-1 and NLRP3 inflammasome activation in HT22 hippocampal cells in diabetes. Life Sci 159: 97-103, 2016. 
WHO (World Health Organization): Global Report on Diabetes. 2016, 88 p.

WONGCHITRAT P, LANSUBSAKUL N, KAMSRIJAI U, SAE-UNG K, MUKDA S, GOVITRAPONG P: Melatonin attenuates the high-fat diet and streptozotocin-induced reduction in rat hippocampal neurogenesis. Neurochem Int 100: 97-109, 2016.

WOSISKI-KUHN M, ERION JR, GOMEZ-SANCHEZ EP, GOMEZ-SANCHEZ CE, STRANAHAN AM: Glucocorticoid receptor activation impairs hippocampal plasticity by suppressing BDNF expression in obese mice. Psychoneuroendocrinology 42: 165-177, 2014.

ZHANG L, CHOPP M, ZHANG Y, XIONG Y, LI C, SADRY N, RHALEB I, LU M, ZHANG ZG: Diabetes mellitus impairs cognitive function in middle-aged rats and neurological recovery in middle aged rats after stroke. Stroke 47: 2112-2118, 2016.

ZHANG X, YEUNG PK, ACALONAN GM, CHUNG SS, CHUNG SK: Transgenic mice over-expressing endothelial endothelin-1 show cognitive deficit with blood-brain barrier breakdown after transient ischemia with long-term reperfusion. Neurobiol Learn Mem 101: 46-54, 2013.

ZHEN YF, ZHANG J, LIU XY, FANG H, TIAN LB, ZHOU DH, KOSTEN TR, ZHANG XY: Low BDNF is associated with cognitive deficits in patients with type 2 diabetes. Psychopharmacology 227: 93-100, 2013. 